\section{MAYER'S PAPERS ON THE CONSERVATION OF ENERGY.}

THE recent issue as one of the volumes of Ostwald's Mayer's two papsiker der exakten Wissenschaften" of Robert known as the conservation of energy, will prove a great boon to those interested in the early history of that great generalisation. Traces of the idea may be found amongst the ancients, and Descartes held that it was a self-evident truth. But in the middle of the seventeenth century the term energy had but a vague significance, even in the simple case of a moving body, and the doctrine of conservation, when held, meant little or nothing for physical science. Towards the middle of the nineteenth century interest in the question appears to have been widespread. Séguin in France in 1839 calculated the mechanical equivalent of heat from the fall of temperature of steam when expanding against external pressure; Joule in England in 1840 showed that when a battery of cells drives a motor the consumption of zinc in the cells is proportional to the work done by the motor; and Mayer in Germany, after explaining how the term energy was to be understood, stated the generality of the law in his first paper in 1842 , and with greater clearness in his pamphlet of 1845

The titles of Mayer's publications were not such as to suggest the subjects treated in them, and they were so little known, even in Germany, that Helmholtz in 1847 published his paper on the subject without any reference to Mayer. In the meantime, Colding in Denmark had read a paper to the Royal Society of Copenhagen in 1843 in which he stated clearly the law of conservation of energy, and Joule read before the British Association in the same year the first of his papers on the measurement of the mechanical equivalent of heat. Before the middle of the century Joule's experimental work had placed thermodynamics on a firm basis. When the contributions of Séguin and of Colding, and possibly of others whose work has been overlooked, are republished in a form as accessible as are those of Mayer, Joule, and Helmholtz, it may be possible to apportion the credit for one of the greatest generalisations of the nineteenth century in a way to satisfy even the most captious critic.

\section{NATURAL SELECTION IN MAN.}

M R. E. C. SNOW, in his paper entitled "The Intensity of Natural Selection in Man " (Drapers' Company Research Memoirs, Studies in National Deterioration, No. vii. London: Dulau and Co., I9II), has set himself to answer the following question: Has heavy infantile mortality any selective value or tendency to eliminate the more sickly and to spare the hardier children? Of the data available for the investigation of this problem, the most satisfactory are derived from the annual volumes of Prussian statistics, and the most definite of the results were obtained from them. In order to indicate the method employed, one example will be described. Thirty rural districts in Prussia were taken, and all the children in them born in the year' I $88 \mathrm{x}$ were considered. It was ascertained for each district how many of these children died in the first two years of life and how many. in the next eight. Now it is obvious that if the infantile mortality tends to weed out the weaker children, then in those districts in which the mortality among the children born in I88I was highest in the years 1881 and 1882 it should tend to be lowest in, the years $1883-90$, since stronger children less likely to succumb to the ailments of childhood would have survived their first two years. In other words, there will be a negative correlation between the number of deaths in the first two years of life and the number in the next eight, provided that allowance is made for the total number of births in each district for the year I88I and for the effects of environment. After making these necessary allowances by means of the formula for partial correlation, a coefficient of -0.93 was obtained in the case of males and of -0.85 in the case of females.

These results, considered by themselves, would seem to show that the selective action of infantile mortality was very strongly marked; but it is perhaps unnecessary to say that the author, whose work bears every sign of the most painstaking care and thoroughness, has brought forward a considerable body of additional evidence derived from data of a similar nature collected both in England and Germany. The greater part of it corroborates the conclusion stated above, though the correlation coefficients were in no other cases found to be so high, and in some cases the sign was actually positive. Yet we are of opinion that, on the whole, the author is justified in saying: "Natural selection in the form of a selective death-rate is strongly operative in man in the earlier years of life." A word of praise must be added on the composition of the memoir : it is fair, clear, and interesting.

E. H. J. S

\section{THE KING ON EDUCATION IN INDIA.}

DURING his visit to Calcutta the King-Emperor and Queen-Empress received in the Throne Room an address from the University of Calcutta. The address was read by the Vice-Chancellor of the University, Sir Asutosh Mukharji, and Lord Hardinge, the Governor-General, was present in his capacity of Chancellor of the University. In his reply to the address the King-Emperor said :-

"I recall with pleasure the occasion on which, six years ago, I received from the University of Calcutta the honorary degree of a Doctor of Law, and I am glad to have an opportunity to-day of showing my deep and earnest interest in the higher education of India. It is to the universities of India that I look to assist in that gradual union and fusion of the culture and aspiration of Europeans and Indians on which the future well-being of India so greatly depends. I have watched with sympathy the measures that from time to time have been taken by the universities of India to extend the scope and raise the standards of instruction. Much remains to be done. No university is nowadays complete unless it is equipped with teaching faculties in all the more important branches of the sciences and the arts, and unless it provides ample opportunities for research. You have to conserve the ancient learning and simultaneously to push forward Western science. You have also to build up character, without which learning is of little value. You say that you recognise your great responsibilities. I bid you Godspeed in the work that is before you. Let your ideals be high and your efforts to pursue them unceasing, and, under Providence, you will succeed.

"Six years ago I sent from England to India a message of sympathy. To-day in India I give to India the watchword of hope. On every side I trace the signs and stirrings of new life Education has given you hope; and through better and higher education you will build up higher and better hopes. The announcement was made at Delhi by my command that my Governor-General in Council will allot large sums for the expansion and improvement of education in India. It is my wish that there may be spread over the land a network of schools and colleges, from which will go forth loyal and manly and useful citizens, able to hold their own in industries and agriculture and all the vocations in life. And it is my wish, too, that the homes of my Indian subjects may be brightened and their labour sweetened by the spread of knowledge with all that follows in its train, a higher level of thought, of comfort, and of health. It is through education that my wish will be fulfilled, and the cause of education in India will ever be very close to my heart.

"It is gratifying to me to be assured of your devotion to myself and to my house, of your desire to strengthen the bonds of union between Great Britain and India, and of your appreciation of the advantages which you enjoy under British rule. I thank you for your loyal and dutiful address."

Since the new University Act was passed in I904, considerable and satisfactory progress has been made in India in all branches of education, and the university standards, in particular, have been raised and made more real and effective. There are many signs of educational activity in India, and if the true purpose of education be kept well in mind the country will enter upon an era of increased prosperity based upon increase of knowledge.

NO. 2202, VOL. 88] 